\title{
Estimating the carbon content of the deep mantle with Icelandic melt inclusions
}

\author{
William G.R. Miller ${ }^{a, *}$, John Maclennan ${ }^{\mathrm{a}}$, Oliver Shorttle ${ }^{\mathrm{a}, \mathrm{b}}$, Glenn A. \\ Gaetani $^{\mathrm{c}}$, Véronique Le Roux ${ }^{\mathrm{c}}$, Frieder Klein ${ }^{\mathrm{c}}$ \\ ${ }^{a}$ Department of Earth Sciences, University of Cambridge, Downing Street, Cambridge, \\ CB2 3EQ, UK. \\ ${ }^{b}$ Institute of Astronomy, University of Cambridge, Madingley Road, CB3 OHA, UK. \\ ${ }^{c}$ Woods Hole Oceanographic Institution, Woods Hole, MA 02543, USA.
}

\begin{abstract}
Earth's carbon budget is central to our understanding of the long-term coevolution of life and the planet. Direct observations of surface reservoirs allow for the detailed quantification of their carbon content. However, the carbon content of Earth's deep interior remains poorly constrained. Here we study olivine-hosted melt inclusions from two Icelandic eruptions, with those from the Miðfell eruption allowing us to investigate the carbon content of the deep mantle. Comparison with the previously studied Borgarhraun eruption highlights the presence of deep, plume-sourced mantle material within the Miðfell source region. Miðfell contains trace element-depleted melt inclusions undersaturated in $\mathrm{CO}_{2}$, which have high $\mathrm{CO}_{2} / \mathrm{Ba}(=396 \pm 48)$ and $\mathrm{CO}_{2} / \mathrm{Nb}(=1832 \pm 316)$, though some inclusions preserve even greater relative carbon enrichment. These observations allow us to reconstruct the $\mathrm{CO}_{2}$ content of the bulk Miðfell source as being $>690 \mathrm{ppm}$. By identifying that Miðfell is a mixture of depleted and deep mantle components, we can estimate a $\mathrm{CO}_{2}$ content for the deep mantle component of $1350 \pm 350 \mathrm{ppm}$; a concentration that is over ten times higher than depleted MORB mantle estimates. Assuming that the deep mantle component
\end{abstract}

*corresponding author: wm248@cam.ac.uk 
identified in Miðfell is representative of a global reservoir, then with our new $\mathrm{CO}_{2}$ estimate and by considering a range of representative mantle fractions for this reservoir, we calculate that it contains up to 14 times more carbon than that of the atmosphere, oceans, and crust combined. Our result of elevated $\mathrm{CO}_{2} / \mathrm{Ba}$ and $\mathrm{CO}_{2} / \mathrm{Nb}$ ratios, and carbon enrichment support geochemical bulk Earth carbon models that call for the presence of carbon-rich deep mantle domains to balance Earth's relatively carbon-poor upper mantle and surface environment. Keywords: Deep mantle carbon; Iceland, melt inclusions

\section{1. Introduction}

2 Geological processes have modulated the Earth's atmospheric carbon con3 tent for billions of years (Hayes and Waldbauer, 2006). At the heart of this 4 cycle is a partitioning of carbon between planetary reservoirs, one that has 5 placed the overwhelming majority of carbon in Earth's crust, mantle, and core - (e.g., Dasgupta and Hirschmann, 2010). The carbon flux from these solid-Earth 7 reservoirs to the atmosphere is efficiently returned via silicate weathering (e.g., 8 Walker et al. 1981), maintaining a habitable climate, and closing the loop on - a cycle that has helped maintain liquid water at Earth's surface over almost its 10 entire history (Mojzsis et al., 2001).

To understand how Earth has come to operate such a stable and long-lasting chemical cycle, it is key to know how carbon is distributed among its reservoirs (Hirschmann, 2016). Whilst for the atmosphere, oceans, and to some extent the crust, their carbon content can be measured directly, quantifying the carbon content of mantle reservoirs is more challenging. Two basic problems frustrate 16 accurate estimation of mantle carbon content: (i) the low solubility of carbon 17 in basaltic melts (Shishkina et al., 2010), which means that information on high-carbon mantle domains is preferentially lost as their melts begin to degas at high pressure in the crust or shallow mantle; and (ii) the partial view that 
volcanism provides of the mantle, with the vast majority of magmas tapping the depleted upper mantle. Only rarely do volcanics display evidence for the involvement of deep-sourced material in their petrogenesis: such occurrences are usually linked to the presence of mantle plumes. These compounding problems cause considerable uncertainty in previously published mantle carbon estimates.

In this paper we present new observations that help constrain the amount of carbon in the deep mantle reservoir. In Section 2, we review the geochemical constraints available on mantle carbon, and identify the observational gaps in our present reservoir inventories. We next present our methods (Section 3) and new data (Section 44 from two Icelandic eruptions, demonstrating that their geochemical characteristics are suited to quantify the amount of carbon in the deep mantle. We show that one of these eruptions, Miðfell, contains melt inclusions that are undegassed and relatively enriched in carbon compared to lithophile trace elements of similar mineral-melt compatibility (Section 5). In Section 6. we use these results to place a new constraint on the deep mantle carbon content, and in Section 7 discuss the implications of this constraint for the origin and distribution of carbon in the Earth.

\section{Measuring mantle carbon}

An enormous amount of work, especially over the last two decades, has focused on measuring the carbon content of mantle-derived volcanics. Despite this effort, surprisingly few observations provide tight constraints on upper mantle carbon content, and fewer still on deep mantle carbon. This section aims to contextualise the present study with this body of work, and identify the features that, in subsequent sections, will mark our new observations as distinct from pre-existing data sets. 


\subsection{The upper mantle}

Mid-ocean ridge basalts (MORBs) sample the most accessible mantle reservoir, the depleted MORB mantle (DMM). Although a shallow reservoir in the context of the mantle, the DMM can be a component of deep-sourced mantle plume magmas, as is the case on Iceland (Stracke, 2012).

A key technique for estimating carbon in DMM is to find an incompatible lithophile trace element (ITE) to reference MORB carbon concentrations against, thereby providing a control for fractionation during mantle melting and crustal differentiation. Estimates of source mantle ITE concentration (e.g., Workman and Hart, 2005) then enable calculation of a source carbon content. $\mathrm{Ba}$ and $\mathrm{Nb}$ are commonly chosen as reference elements because they have similar compatibility to carbon during peridotite melting (Rosenthal et al., 2015). However, as $\mathrm{Ba}$ and $\mathrm{Nb}$ are not volatile, accurate estimation of source carbon is dependent on either finding melts that are $\mathrm{CO}_{2}$ undersaturated, or reconstructing pre-degassed $\mathrm{CO}_{2}$. A degassing correction has been applied to some highly vesicular glass samples, which re-coupled $\mathrm{CO}_{2}$ to ITE concentrations, giving DMM carbon estimates of $393 \pm 82 \mathrm{ppm} \mathrm{CO}_{2}$ using $\mathrm{CO}_{2} / \mathrm{Nb}=534$, and $427 \pm 45 \mathrm{ppm} \mathrm{CO}_{2}$ using $\mathrm{CO}_{2} / \mathrm{Ba}=106$ (Table 1; $14^{\circ} \mathrm{N}$ Mid-Atlantic Ridge; Cartigny et al., 2008). We note that whilst carbon exists in the mantle in oxidised and reduced forms (Dasgupta and Hirschmann, 2010), for ease of comparison between data sets, we report total carbon as $\mathrm{CO}_{2}$.

Only rare suites, such as some pillow glasses erupted at relatively high pressure and with intrinsically low carbon content, may show undersaturated volatile concentrations. Michael and Graham (2015) used such samples to estimate a DMM $\mathrm{CO}_{2}$ of $59 \pm 39 \mathrm{ppm}$ (Table 1. $\mathrm{CO}_{2} / \mathrm{Ba}=105$; Global MORB). A difficulty with this approach is in having confidence that measured melts are truly undegassed. Saal et al. (2002) emphasised how linearly correlated carbon-trace 
element concentrations can validate a data set as having undersaturated melt populations. However, Matthews et al. (2017) presented a forward model to suggest that such correlations can readily arise from the mixing of variably degassed melts at low pressure. They concluded that to have more confidence in identifying undegassed melts, data will ideally show some melts with high ITE content that have clearly degassed to their saturation concentration (i.e., no ITE-carbon correlation), and others with lower ITE and carbon content where an ITE-carbon correlation persists; such suites evidence incomplete melt mixing. Data sets exhibiting such structure offer the best chance for empirically separating degassed and undegassed melt populations.

Applying the insights from Matthews et al. (2017) can make certain data sets difficult to empirically validate for carbon undersaturation. For example, observations of quenched matrix glasses, for which the melt has been largely homogenised prior to eruption (i.e., many seafloor basalts; Shorttle, 2015; Michael and Graham, 2015), do not provide data sets that can be internally validated: giving only one $\mathrm{CO}_{2}$ and ITE content per eruption. One solution is to use olivine-hosted melt inclusions, which, when trapped at high pressure, may capture melts with both undegassed carbon and chemical diversity that has not been homogenised by mixing (Maclennan, 2008b). Melt inclusion studies have thus been key in characterising upper mantle carbon: their results suggest that the DMM contains carbon heterogeneity, as both $\mathrm{CO}_{2} /$ ITE ratios and estimated ITE concentrations vary (Le Voyer et al., 2017), with carbon concentrations ranging from 22-427 ppm $\mathrm{CO}_{2}$ (Table 1; Siqueiros, Saal et al. 2002, Mid-Atlantic Ridge, Cartigny et al., 2008, Le Voyer et al., 2017).

\subsection{The deep mantle}

We use the term 'deep mantle' to refer loosely to the region of Earth's convecting mantle that is not represented by the composition of typical MORB. 
The geometry of this reservoir is poorly constrained, and its upper horizon could fall anywhere from the mantle transition zone, to the large low shear velocity provinces above the core-mantle boundary (e.g., Hofmann, 1997). Upwelling plumes can bring this deep mantle material into the upper mantle and melt it at shallow levels. Whatever its locus, the deep mantle appears to comprise primitive material that has remained isolated for billions of years (e.g., Mukhopadhyay, 2012, Peters et al., 2018), as well as crustal material introduced via recycling processes (e.g., Nestola et al., 2018). Both components could be significant carbon reservoirs: primitive material potentially containing solar nebular carbon, which dissolved into Earth's early magma ocean along with noble gases (e.g., Williams and Mukhopadhyay, 2018); whereas, recycled material could introduce organic or inorganic carbon from the surface (e.g., Nestola et al., 2018).

Ocean island basalts (OIBs) are prime candidates in the search for deep mantle carbon. Geochemical observations have consistently shown OIB to have more evidence of both recycled and primitive mantle components than MORB (e.g., Hofmann, 1997), and in many cases geophysical observations support their lower mantle origins (e.g., Montelli et al., 2006). Beneath Iceland specifically, the hot, low velocity, plume conduit has been seismically imaged through the deflected transition zone (Jenkins et al., 2016), and down into the lower mantle (Yuan and Romanowicz, 2017).

The nature of magma generation and eruption at ocean island settings typically results in OIB degassing (Gonnermann and Mukhopadhyay, 2007): low eruption or melt inclusion entrapment pressures combine with high initial dissolved $\mathrm{CO}_{2}$ content, derived from low degree melting and/or carbon-rich source material. This degassing can, however, be an advantage if rather than measuring the melt, the degassed $\mathrm{CO}_{2}$ flux is measured. Anderson and Poland (2017) mea- 
sured $\mathrm{CO}_{2}$ degassing at Hawaii, along with a melt production rate to estimate the Hawaiian source mantle carbon content to be $962+296 /-227$ ppm $\mathrm{CO}_{2}$. This estimate is significantly higher than that obtained from MORB (Table 1), a discrepancy suggesting the presence of high carbon regions in Earth's deep mantle. However, bulk degassing cannot be used to uniquely assign carbon to the recycled (e.g., Sobolev et al., 2005) or primitive (e.g., Trieloff et al., 2000) components inferred for the Hawaiian source. Our approach minimises this ambiguity by focusing on melt inclusions from single eruptions.

\subsection{Bulk silicate Earth carbon estimates}

In principle, the size of the bulk silicate Earth (BSE) carbon reservoir could be reconstructed using carbon estimates of all mantle reservoirs, including the deep mantle. However, as emphasised above, a key piece of information is poorly known: the size of this deep mantle reservoir (Hofmann, 1997). A common approach to this problem is to assume, or infer from geochemical mass balance, the size of the deep mantle reservoir and then use carbon-gas or carbon-trace element ratios to extrapolate to bulk Earth.

A recent review paper from Halliday (2013) presented several models for estimating bulk Earth carbon content. The 'basalt' model used the water content of MORB and OIB to infer a bulk water content for the entire mantle, and then took representative $\mathrm{H} / \mathrm{C}$ ratios to calculate a bulk mantle carbon content (163 ppm $\mathrm{CO}_{2}$ ). The 'layered mantle' model used $\mathrm{Ar}$ isotope budgets across all Earth's reservoirs, along with volatile ratios, to derive a bulk Earth carbon budget of $2462 \mathrm{ppm} \mathrm{CO}_{2}$. This estimate is very similar to the value from Marty (2012), who also used an ${ }^{40} \mathrm{Ar}$ budget to extrapolate observed $\mathrm{C} / \mathrm{N}$ and $\mathrm{C} /{ }^{4} \mathrm{He}$ ratios to the whole Earth (2831 ppm $\mathrm{CO}_{2}$ ).

Carbon-ITE ratios in MORB, enriched-MORB, and OIB have also been used to reconstruct BSE carbon. Hirschmann (2018) presented a recent implementa- 
tion of this approach, taking $\mathrm{CO}_{2} / \mathrm{Ba}=100 \pm 20$ for the convecting mantle and a representative $\mathrm{Ba}$ concentration to estimate $514 \pm 147 \mathrm{ppm} \mathrm{CO}_{2}$ in $\mathrm{BSE}$. This new estimate assumes that oceanic basalts, regardless of enrichment, preserve similar $\mathrm{CO}_{2} / \mathrm{Ba}$ ratios, and that analysed oceanic basalts sample all significant geochemical reservoirs within the Earth. Our new results will show, in contrast, that there is evidence for both significant $\mathrm{CO}_{2} / \mathrm{Ba}$ variability, and that there exist mantle reservoirs with far higher $\mathrm{CO}_{2} / \mathrm{Ba}$ than have previously been identified in MORB or OIB.

Whilst the above BSE carbon estimates vary significantly, they have a common implication: assuming DMM carbon concentrations of 20-100 ppm $\mathrm{CO}_{2}$ (e.g., Dasgupta and Hirschmann, 2010), a significantly more carbon-rich reservoir must exist in the deep Earth to balance high BSE carbon estimates. For example, Hirschmann (2016) calculated that this reservoir needs $\mathrm{CO}_{2} / \mathrm{Nb}=5000$ \pm 2000 and $\mathrm{CO}_{2} / \mathrm{Ba}=850 \pm 350$ to match the BSE carbon content calculated by Marty (2012).

\subsection{Carbon in the Icelandic mantle}

Previous studies of Icelandic geothermal fluids, glasses and vesicles have concluded that the Icelandic mantle source has little to no carbon enrichment with respect to DMM. While these studies used bulk analyses to assess average source carbon, our study uses olivine-hosted melt inclusions to access signals of source heterogeneity that are preserved in melts prior to mixing.

Only one melt inclusion suite from Iceland has previously been interrogated for mantle carbon signatures; the Borgarhraun eruption in the Northern Rift Zone (NRZ, Fig. 17). Olivine-hosted melt inclusions from Borgarhraun record compositional heterogeneity (Maclennan et al., 2003), show evidence of concurrent crystallisation and melt mixing (Maclennan, 2008a), and preserve a $\mathrm{CO}_{2}$-ITE correlation (Hauri et al. 2018), which has been used as evidence for 
an undegassed $\mathrm{CO}_{2}$ signature $\left(\mathrm{CO}_{2} / \mathrm{Ba}=48.3 \pm 2.7, \mathrm{CO}_{2} / \mathrm{Nb}=391 \pm 16\right.$; Table 11. The mantle carbon content inferred from these observations is similar to that of DMM, with $\mathrm{CO}_{2} / \mathrm{Nb}$ comparable to undegassed MORB suites (Table 1 , but with $\mathrm{CO}_{2} / \mathrm{Ba}$ half the inferred global average (Hirschmann, 2018).

Borgarhraun melts are not strongly enriched in lithophile elements, being depleted relative to other Icelandic melts, and its He isotope signature $\left(R / R_{a}\right.$ $=7.9$; Fig. 1 1 ) lies within the MORB range (Füri et al., 2010). Hauri et al. (2018) suggested that the Borgarhraun mantle contains a source common to the Atlantic depleted mantle: hydrated and carbonated material originating from subduction-related modification. These features strongly suggest that there is no deep mantle component in the Borgarhraun source, which fits the regional systematics of 'MORB-like' He-Ne in NRZ eruptions in contrast to more 'solarlike' noble gas compositions of Western Rift Zone (WRZ) eruptions (e.g., Füri et al., 2010). Such observations align with $\mathrm{Pb}$ isotope constraints indicating distinct mantle source components across Iceland (Shorttle et al., 2013), and merit investigation of whether there are associated differences in mantle carbon abundances between the two rift zones. Our new observations from eruptions in the WRZ and central Iceland (Fig. 1a) directly address this question.

\section{Samples and methods}

\subsection{Geological context}

We present new data from two Icelandic eruptions, Miðfell (also known as Dagmálafell; $64^{\circ} 10.456^{\prime} \mathrm{N}, 021^{\circ} 02.859^{\prime} \mathrm{W}$ ) and Kistufell (64 $47.442^{\prime} \mathrm{N}$, 017 10.456' W; Fig. 1 1a). Miðfell is a $~ 300 \mathrm{~m}$ high mountain in Iceland's WRZ, lying on the eastern edge of Pingvallavatn and within the Hengill volcanic system. It is a northeast-southwest striking ridge, which is thought to have erupted beneath ice during the last glacial period (Gurenko and Chaussidon, 1995, and 
references therein). The mountain's lower flanks comprise vesicular, olivinephyric, pillow basalts with glassy rinds, whereas the upper portions are composed of hyaloclastite. Kistufell is a table mountain located in central Iceland, at the northern edge of Vatnajökull. Kistufell may have erupted towards the end of the last glacial period as the ice-sheet retreated (Breddam, 2002). Glassy pillows are exposed at the northern flanks of the mountain.

\subsection{Geochemical context}

Previous Miðfell melt inclusion studies have measured significant trace element variability, including high-degree melts with diluted ITE concentrations (Gurenko and Chaussidon, 1995). If carbon remained coupled to these ITE's, then it is likely that some Miðfell melt inclusions have avoided degassing, providing an opportunity to recover mantle carbon content. Both Miðfell and Kistufell have noble gas isotope data that support the presence of primordial material in their source regions: $\mathrm{R} / \mathrm{R}_{\mathrm{a}} \sim 17$ (Breddam et al., 2000, Füri et al., 2010) and, where heavy noble gases have been measured in Miðfell, primordial Xe and Ne isotopic ratios (Mukhopadhyay, 2012). Miðfell olivines and matrix glass also show noble gas evidence for other components, including recycled air (e.g., Harrison et al., 1999). Combined, these observations make Miðfell and Kistufell good targets for identifying deep mantle carbon.

\subsection{Analytical methods}

Olivine phenocrysts $0.5-4 \mathrm{~mm}$ in size were picked from hand-crushed pillow glasses. Care was taken to pick unaltered olivine macrocrysts containing glassy melt inclusions without post-entrapment crystals. Olivines were individually mounted and polished to expose melt inclusions before being re-mounted and polished for analysis. Melt inclusions were analysed for trace elements, $\mathrm{CO}_{2}$, and $\mathrm{H}_{2} \mathrm{O}$ by secondary ion mass spectroscopy at the Edinburgh ion microprobe 
facility. Major elements were measured by electron probe microanalysis. A subset of the Miðfell melt inclusion suite was processed at Woods Hole Oceanographic Institution to reconstruct their initial $\mathrm{CO}_{2}$ content from vapour bubble and inclusion glass $\mathrm{CO}_{2}$ concentrations. Melt inclusion and vapour bubble volumes were determined by X-ray tomography. Vapour bubble $\mathrm{CO}_{2}$ content was determined using confocal Raman spectroscopy. For full method details and representative melt inclusion micrographs, see Supplementary Material.

\section{Results}

\subsection{Major elements}

Miðfell olivine phenocryst compositions range from $\mathrm{Fo}_{90.9}$ to $\mathrm{Fo}_{85.2}$ (Fig. 2), the matrix glass and olivine-hosted melt inclusion compositions are basaltic ( $\mathrm{SiO}_{2} \sim 48 \mathrm{wt} \%$ ), giving a picritic whole rock composition (Gurenko and Chaussidon, 1995). Kistufell olivines range from $\mathrm{Fo}_{89.7}$ to $\mathrm{Fo}_{87.9}$ with basaltic melt inclusions $\left(\mathrm{SiO}_{2} \sim 48 \mathrm{wt} \%\right)$.

Melt inclusion major element compositions have been corrected for postentrapment crystallisation by iteratively adding an equilibrium olivine composition, assuming an Fe-Mg $\mathrm{K}_{\mathrm{D}}=0.34$ (Matzen et al., 2011), until the melt inclusion reached equilibrium with its host (Danyushevsky et al. 2000). For Miðfell, this correction takes into account the ferric iron content of each melt inclusion (see Supplementary Material), whereas for Kistufell we assumed a constant ferric to total iron ratio of 0.07 based on matrix glass measurements (Breddam. 2002). The majority of melt inclusions required $<5 \%$ olivine addition to bring them back into Fe-Mg equilibrium with their olivine host.

\subsection{Trace elements}

Miðfell melt inclusions record substantially more variability than those from Kistufell (Fig. 2 \& 3). The method of Maclennan et al. (2003) was used to 
establish that the Miðfell analyses for all major, trace, and volatile elements (apart from $\mathrm{H}_{2} \mathrm{O}, \mathrm{Yb}$ and $\mathrm{Lu}$ ) have a signal-to-noise ratio $>1$, and $>99 \%$ confidence that natural variability can be resolved from analytical noise. These inclusions preserve trace element variability comparable with that found by the combination of all previously published undegassed melt inclusion and MORB glass suites (e.g., Saal et al., 2002). Kistufell melt inclusions recover a signal-tonoise ratio $>1$ for the majority of major, trace, and volatile elements. However, the Kistufell melt inclusion suite has much lower melt heterogeneity than Miðfell, as indicated by their contrasting signal-to-noise ratios (e.g., Miðfell $\sigma_{\mathrm{t}} /\left.\sigma_{\mathrm{r}}\right|_{\mathrm{Ba}}=$ 86.4; Kistufell $\left.\sigma_{\mathrm{t}} /\left.\sigma_{\mathrm{r}}\right|_{\mathrm{Ba}}=3.06\right)$.

Multi-element plots (Fig. 3) illustrate Miðfell and Kistufell trace element variability compared to that of the Borgarhraun eruption (Hauri et al. 2018). As is typical for many mantle-derived basalts, the most incompatible trace elements show the largest concentration range. In Miðfell, Ba content ranges from 0.37-115 ppm (29.8-3.5\% relative error; matrix glass $6.3 \mathrm{ppm})$, and $\mathrm{Nb}$ content ranges from $0.04-22.9 \mathrm{ppm}$ (17.6-9.1\% relative error; matrix glass $0.78 \mathrm{ppm}$ ). Vapour bubbles only occur in Miðfell melt inclusions with high trace element concentrations $(>12.4 \mathrm{ppm} \mathrm{Ba}$ and $>2.47 \mathrm{ppm} \mathrm{Nb})$. Kistufell melt inclusions rarely contain vapour bubbles, so no inclusions with vapour bubbles were measured for this data set. Trace element patterns in all three eruptions show that some of the melt inclusions preserve positive $\mathrm{Sr}$ and negative $\mathrm{Zr}$ anomalies, consistent with previous Miðfell melt inclusion analyses (Gurenko and Chaussidon, 1995).

\subsection{Volatile elements}

Kistufell melt inclusions have a water content that matches that of the matrix glass surrounding host olivines, but the sample population shows some variability $(0.10-0.19 \mathrm{wt} \%)$. Water content in the Miðfell melt inclusions and matrix 
glass is almost constant at $\sim 0.06 \mathrm{wt} \%$, which is low compared to other Icelandic melt inclusion suites (e.g., Laki, $\sim 0.65 \mathrm{wt} \% \mathrm{H}_{2} \mathrm{O}$, Hartley et al., 2015). Melt inclusion $\mathrm{CO}_{2}$ content varies from $20-1120$ ppm (Fig. 4 4). At low trace element concentrations $(\mathrm{Ba}<3.0 \mathrm{ppm}, \mathrm{Nb}<0.2 \mathrm{ppm})$ the maximum melt inclusion $\mathrm{CO}_{2}$ content is controlled by $\mathrm{CO}_{2} / \mathrm{ITE}$ ratios. At higher trace element concentrations, maximum $\mathrm{CO}_{2}$ content reaches a plateau at $1120 \mathrm{ppm}$. Melt inclusions containing vapour bubbles record a glass $\mathrm{CO}_{2}$ content of 720-1170 ppm, consistent with the vapour bubble-absent inclusions, and a total (reconstructed) $\mathrm{CO}_{2}$ content of 1340-4550 ppm (Fig. 4a). Matrix glass has a $\mathrm{CO}_{2}$ content of $<200 \mathrm{ppm}$.

\section{4. $\mathrm{CO}_{2} /$ ITE ratios}

Kistufell melt inclusions record maximum $\mathrm{CO}_{2} / \mathrm{Nb}=391 \pm 70$ and $\mathrm{CO}_{2} / \mathrm{Ba}$ $=71.9 \pm 13.9$, which are associated with the lowest ITE concentration melts. Miðfell melt inclusions preserve maximum $\mathrm{CO}_{2} / \mathrm{Nb}=5737 \pm 987$ and $\mathrm{CO}_{2} / \mathrm{Ba}$ $=566 \pm 68$, also associated with low trace element concentrations, i.e., lower than the matrix glass (Fig. 5), and hosted in the most forsterite-rich olivines (Fig. 2b). Melt inclusions with $\mathrm{CO}_{2}$ content reconstructed from vapour bubble concentrations also have high $\mathrm{CO}_{2} /$ ITE ratios, with maximum $\mathrm{CO}_{2} / \mathrm{Nb}=$ $1186 \pm 127$ and $\mathrm{CO}_{2} / \mathrm{Ba}=236 \pm 25$. Comparison to previously analysed melt inclusion and MORB glass suites shows that the Miðfell melt inclusions preserve some of the highest $\mathrm{CO}_{2} /$ ITE ratios ever measured in natural basaltic glass (e.g., Le Voyer et al. 2017). Importantly, Miðfell inclusions exhibit these higher $\mathrm{CO}_{2}$ /ITE ratios at the same ITE concentrations as in previously studied suites, indicating that their relative carbon enrichment is not a feature of anomalous trace element depletion or enrichment (Fig. 5). 


\section{Does Miðfell preserve a mantle carbon signature?}

The previous section demonstrated that whilst Miðfell melt inclusions preserve significant trace element variability, Kistufell contains a more homogeneous melt inclusion population. On this basis, the Kistufell melt inclusions do not enable empirical validation of whether they have degassed carbon (Fig. $4 \mathrm{~b}$; Matthews et al. 2017). However, Kistufell melt inclusions have ITE concentrations that in the Miðfell melt inclusion population are associated with carbon loss (Fig. 4). For Miðfell, this carbon loss is shown by systematically decreasing $\mathrm{CO}_{2}$ /ITE ratios with increasing ITE concentration (Fig. 55,d). Kistufell inclusions have likely degassed, therefore we focus our investigation of deep mantle carbon onto the Miðfell inclusions, where we can be sure of recovering undegassed systematics.

Trace element and $\mathrm{CO}_{2}$ data from Miðfell melt inclusions suggest that some process has enriched these basaltic glasses in carbon, relative to ITE's, compared with other inclusion and glass suites (e.g., Michael and Graham, 2015). To use this observation to constrain the carbon content of the Miðfell mantle source first requires an assessment of the influence of crustal processes, which could have affected the carbon and ITE content of Miðfell melts.

\subsection{Degassing and olivine decrepitation}

The strongest signal in the Miðfell $\mathrm{CO}_{2}$ data, seen most clearly at trace element concentrations greater than that of the matrix glass, is one of degassing (Fig. 4a). At these high ITE concentrations, melt inclusions with variable trace element concentrations have constant $\mathrm{CO}_{2}$ content, indicating the partial loss of initial $\mathrm{CO}_{2}$, and therefore loss of information on carbon from deeper in the system. If degassing occurred in some of the Miðfell melts prior to entrapment, then solubility models suggest entrapment pressures of $\sim 1.8$ kbar (taking 1170 ppm $\mathrm{CO}_{2} ;$ Shishkina et al., 2010). 
However, the presence of vapour bubbles in some of the trace element enriched melt inclusions suggests that some Miðfell melts were initially trapped with higher dissolved $\mathrm{CO}_{2}$ concentrations and underwent exsolution post-entrapment. Reconstructed $\mathrm{CO}_{2}$ concentrations from these inclusions are consistent with saturation pressures of up to $\sim 4.5 \mathrm{kbar}(\sim 13 \mathrm{~km}$ depth). If all melts started with the same $\mathrm{CO}_{2} / \mathrm{ITE}$ ratio, then those $\mathrm{CO}_{2}$-saturated melt inclusions lacking vapour bubbles must have lost exsolved $\mathrm{CO}_{2}$ during ascent to eruption, perhaps by decrepitation (Maclennan, 2017).

ITE-rich Miðfell melts appear to have been degassed to their saturation concentration, but at lower ITE concentrations melts show an ITE- $\mathrm{CO}_{2}$ correlation. This observation suggests that ITE-depleted melt inclusions preserve an undegassed $\mathrm{CO}_{2}$ signal (Matthews et al., 2017); an inference supported by bubble-reconstructed melt inclusions that have $\mathrm{CO}_{2} /$ ITE ratios in broad agreement with those of depleted inclusions (Fig. $4 \&$ 5). Therefore, relative carbon enrichment in Miðfell was likely not restricted to the most ITE-depleted melts, but rather a characteristic of all ITE concentrations (Fig. 4a \& 5). With this result, the key question is what source or process led to high $\mathrm{CO}_{2} /$ ITE ratios in Miðfell inclusions?

\subsection{Crustal melt modification}

Gurenko and Sobolev (2006) analysed olivine-hosted melt inclusions and gabbroic xenoliths from Miðfell to infer that the trace element chemistry of Miðfell melt inclusions had been modified by interaction with lower crustal gabbro. To attribute a carbon enrichment signature to the mantle, we must identify melt inclusions that have avoided $\mathrm{CO}_{2} /$ ITE ratio modification by crustal interaction.

We have modelled the mixing of a depleted Miðfell melt composition, which has a smooth trace element pattern, with crustal components. We discount a role for significant plagioclase addition to Miðfell melts (Fig. S5). However, 
mixing with a $10 \%$ fractional melt derived from Miðfell gabbro best matches the shape of positive $\mathrm{Sr}$, negative $\mathrm{Zr}$, and $\mathrm{Ba}>\mathrm{Nb}$ anomalies observed within some of the Miðfell melt inclusion population (Fig. $3 \&$ S6), providing good evidence for interaction between primitive Miðfell melts and gabbro in the crust.

Extending our analysis to assess the impact of crustal interaction on $\mathrm{CO}_{2} / \mathrm{ITE}$ ratios; an important observation is that carbonate phases have not been seen in Miðfell gabbroic xenoliths (Gurenko and Sobolev, 2006), though carbonate breakdown on decompression during eruption may remove visible evidence of gabbroic carbon (e.g., Canil, 1990). Therefore, the addition of carbon to Miðfell melts cannot be ruled out from textural observations, but geochemical observations can be used to avoid melt inclusions that have strongly interacted with gabbroic material, i.e., those having large trace element anomalies.

To avoid the effects of any potential $\mathrm{CO}_{2}$-ITE modification, in the subsequent analysis we have only used melt inclusions with smooth trace element patterns. We believe that these melt inclusions have had minimal interaction with crustal gabbro during ascent through the Miðfell magmatic system.

Melt inclusions with smooth trace element patterns record maximum $\mathrm{CO}_{2} / \mathrm{Nb}$ $=1832 \pm 316$ and $\mathrm{CO}_{2} / \mathrm{Ba}=396 \pm 48$ (Fig. 5s,d), again showing higher ratios than observed in MORB suites, and suggesting that the relative carbon enrichment in Miðfell melts likely originates in its source mantle.

\section{Estimating the carbon content of the Miðfell mantle source}

The key question we address in this section is whether the observed high $\mathrm{CO}_{2} / \mathrm{Ba}$ and $\mathrm{CO}_{2} / \mathrm{Nb}$ ratios in Miðfell inclusions require an anomalously carbonrich mantle source. First we identify which ITE's have stayed coupled to carbon during the melting process, and hence which $\mathrm{CO}_{2} /$ ITE ratios are unfractionated from their source values. We then review the mantle components contributing 
to Miðfell and calculate in what relative proportions they are represented in its chemistry. Finally, we use constraints on ITE concentrations in these sources to convert the observed $\mathrm{CO}_{2}$ and ITE systematics of Miðfell inclusions into source $\mathrm{CO}_{2}$ concentrations.

\subsection{Carbon-ITE coupling in Miðfell}

The silicate-melt partition coefficient for carbon, as estimated by carbonatedlherzolite melting experiments, places it between $\mathrm{Ba}$ and $\mathrm{Nb}$ in terms of compatibility (Rosenthal et al., 2015). Therefore, we would expect $\mathrm{CO}_{2} / \mathrm{Ba}$ and $\mathrm{CO}_{2} / \mathrm{Nb}$ in Miðfell to be similar to that of its mantle source, provided it represents an aggregation of melts from across the melting region (e.g., Fig. 6 solid line). If instead, Miðfell was produced from high-degree melts from the shallow part of the melting region, a region already extensively depleted by prior melting, then even highly incompatible elements may have been fractionated from each other, so $\mathrm{CO}_{2} / \mathrm{Ba}$ and $\mathrm{CO}_{2} / \mathrm{Nb}$ may not be faithful to the source value (e.g., Fig. 6 dashed and dashed-dotted lines).

We have two tests for whether $\mathrm{CO}_{2} /$ ITE ratios have been fractionated during melting. The first uses the fact that carbon partitioning between silicate and melt lies between that of $\mathrm{Ba}$ and $\mathrm{Nb}$ (Rosenthal et al., 2015). Therefore, if Miðfell represents preferential sampling of high-degree shallow melts, we might expect to observe anomalously high $\mathrm{CO}_{2} / \mathrm{Ba}$. However, this observation would be associated with correspondingly low $\mathrm{CO}_{2} / \mathrm{Nb}$. Instead, Miðfell inclusions show correlated high $\mathrm{CO}_{2} / \mathrm{Nb}$ and $\mathrm{CO}_{2} / \mathrm{Ba}$ values (Fig. 6), indicating that no such fractionation has occurred.

Secondly, fractionation between trace elements during fractional melting will be manifest in the elements' relative variability (their standard deviation divided by their mean concentration). One prediction of fractional melting models is that trace element variability should increase with decreasing partition coeffi- 
cient (red line, Fig. 7, Schiano et al. 1993). Figure 7 shows that in Miðfell inclusions, the most incompatible elements measured (Ba, K, Nb, La) have constant relative variability, which is consistent with a residual porosity during melting having damped the variability generated by low degree melting. As these low degree melts will have contained almost all the $\mathrm{Ba}, \mathrm{K}, \mathrm{Nb}$, and $\mathrm{La}$ that was in the source, these elements will not have been fractionated from each other during the melting event that produced Miðfell. As carbon's partition coefficient lies within the range of Ba to La, we can infer from Fig. 7 that carbon will not have been fractionated from any elements across this range of partition coefficients. Therefore, the uncommonly high $\mathrm{CO}_{2} / \mathrm{Ba}$ and $\mathrm{CO}_{2} / \mathrm{Nb}$ ratios observed in undegassed Miðfell melts (Fig. 5) reflect the composition of their mantle sources.

\subsection{Components in the Miðfell mantle source}

Miðfell's depleted mantle component: the Borgarhraun eruption provides an on-Iceland sample of the local depleted mantle component in the plume (Thirlwall et al., 2004, Stracke et al. 2003), one that has been suggested to be ubiquitous in the Atlantic mantle (Hauri et al., 2018). Similarities in lithophile elements (Fig. 3), including Pb isotopes (Kokfelt et al., 2006; Halldórsson et al. 2016a), between Miðfell and Borgarhraun, suggest that DMM-like Borgarhraun source material is also present as a component within the Miðfell mantle source.

Is there a pyroxenitic component in Miðfell?: The variability in trace element enrichment and major element chemistry of primitive melts from across Iceland has been interpreted to reflect recycled pyroxenitic components in the Icelandic mantle (Sobolev et al., 2008; Peate et al., 2010, Shorttle and Maclennan, 2011). In the case of Miðfell though, trace element ratios (e.g., $\mathrm{Nb} / \mathrm{Zr} \sim 0.05$ ), major elements ( $\mathrm{FeO} \sim 9.4 \mathrm{wt} \%$ ), and $\mathrm{Cl}$ isotopes (Halldórsson et al., 2016a) suggest minimal contribution from pyroxenite material to this eruption. 
This is not to say that Miðfell has had no recycled contribution to its composition. It contains a typical DMM component, which has itself been argued to contain recycled signatures, both as a regional contamination of the upper mantle (Hauri et al., 2018) and as a global phenomenon (Andersen et al., 2015). However, as Borgarhraun does not show significant carbon enrichment with respect to MORB and significantly less relative carbon enrichment than Miðfell, there is no evidence that the Icelandic mantle has been enriched in carbon from pyroxenite addition.

Evidence for a deep mantle component: the Miðfell source incorporates material distinct from that of the MORB source, having a more solar- or carbonaceous chondrite-like composition that is often ascribed to an ancient primordial reservoir. This signal is most distinct in the heavy noble gas isotopes (e.g., Harrison et al., 1999, Trieloff and Kunz, 2005, Mukhopadhyay, 2012, Caracausi et al. 2016).

However, the heavy noble gases also indicate that the Miðfell source has had atmosphere recycled into it (e.g., Harrison et al., 1999). This conclusion is in general consistent with constraints from other isotopic systems, e.g., $\mathrm{N}$ and Os, which suggest that ancient $(>1.5 \mathrm{Ga})$ recycled crust is present within the deep mantle component of the Icelandic mantle plume as crustal isotopic signatures are coupled with high- ${ }^{3} \mathrm{He} /{ }^{4} \mathrm{He}$ values (Brandon et al., 2007; Halldórsson et al. 2016b). Therefore, a deep mantle component could contain carbon of both primordial and recycled origins.

The above observations suggest that the Miðfell source mantle comprises a mixture of a depleted component (DM), akin to Borgarhraun source mantle, and a deep mantle component (Deep). Both the Deep and DM components within the Miðfell source can have plausible estimates made of their ITE content, which will be important for estimating source $\mathrm{CO}_{2}$ concentrations. In subsequent mod- 
471 elling we adopt the BSE composition given by McDonough and Sun (1995) for

472 the Deep component, though we note that its ITE composition could be more 473 enriched due to recycled material. As there are no constraints on the nature 474 of this enrichment, we do not propagate this uncertainty, although we empha475 sise that by assuming a BSE source rather than BSE + recycled source, our 476 source carbon estimates will be a lower bound. We assign the DM component 477 the Borgarhraun source mantle ITE composition (Hauri et al., 2018). As the ${ }_{478} \mathrm{CO}_{2}$ of DM has been estimated, only Deep $\mathrm{CO}_{2}$ and the DM:Deep proportions 479 are unknowns in estimating source $\mathrm{CO}_{2}$. Neither choice of source composition is critical to the results we subsequently obtain: similar source carbon concentrations are inferred if we take, for example, ITE abundances from Palme and ${ }_{482}$ O'Neill (2014) for the Deep estimate and Workman and Hart (2005) for the 483 DM.

6.3. Proportions of depleted and deep components in the Miðfell mantle source

If $\mathrm{Ba}, \mathrm{K}, \mathrm{Nb}, \mathrm{La}$, and carbon have not been fractionated from each other during melting, then their proportions in Miðfell reflect the degree of melting, $F$; melt mixing; and melt transport: partial melting will have enriched these ITE's in the melt compared to their source concentrations. Using estimates of $\mathrm{Ba}, \mathrm{K}, \mathrm{Nb}$, and La content of both $\mathrm{DM}$ and Deep components constituting the Miðfell source, we can calculate how much the melting process has enriched Miðfell compared to its mantle source, and thereby calculate the source carbon content. We define the enrichment factor for an element, $i$, as

$$
E_{i}=\frac{C_{i}^{l}}{C_{i}^{0}},
$$

where $C_{i}^{l}$ is the concentration of the element in the liquid (i.e., observed Miðfell) and $C_{i}^{0}$ is the concentration of the element in the source (DM and Deep taken from Hauri et al. 2018 and McDonough and Sun, 1995, respectively). For Ba, 
$\mathrm{K}, \mathrm{Nb}$, and La we can calculate $E_{i}$ directly, assuming a DM:Deep ratio. For carbon, we take the mean enrichment factor estimated from the lithophile trace elements, and use it in (1) with the observed carbon content of Miðfell inclusions to estimate $C_{C}^{0}$. The main question is what mass fraction of the Miðfell source is the Deep component? The enrichment factor contains information on this fraction: given that $\mathrm{Ba}, \mathrm{K}, \mathrm{Nb}$, and $\mathrm{La}$ have not been fractionated during melting, and if we have identified the correct Deep and DM source compositions, then $E_{\mathrm{Ba}}=E_{\mathrm{K}}=E_{\mathrm{Nb}}=E_{\mathrm{La}}$. Therefore, by sweeping through Deep component fractions from 0 to 1 and identifying the minimum amount of variability in $E_{i}$, we can identify the optimal source mixture.

In Fig. $8 \mathrm{a}$ we show the mean enrichment factor, $\bar{E}$, calculated from $\mathrm{Ba}$, $\mathrm{K}, \mathrm{Nb}$, and La content of the Miðfell matrix glass (i.e., the composition of the aggregated melt) as a function of Deep fraction in the source. Figure 8 shows that $\bar{E}$ lies between 1 and 3 in these models. These small enrichment factors likely reflect both the high peak mantle melt extent under Iceland $(\sim 30 \%$; Maclennan et al., 2001) and the incomplete mixing of mantle melts leading to a bias towards relatively shallow fractional melts from the full melting column in the mean Miðfell composition.

When the source is mostly DM (i.e., low $\mathrm{X}_{\text {Deep }}$ ) the $C_{i}^{0}$ values are low, and the $E_{i}$ 's are correspondingly high. The variability in the calculated enrichment factors is minimised at $\mathrm{X}_{\text {Deep }}=0.47$ (Fig. 8b), i.e., a nearly 50:50 mixture of DM and Deep components in the Miðfell source, which corresponds to $\bar{E}=1.56$.

\subsection{Translating enrichment factors to source $\mathrm{CO}_{2}$}

The final step in using the calculated enrichment factors to estimate bulk Miðfell source carbon is to choose a carbon content for the Miðfell magma. For this calculation we take the $\mathrm{CO}_{2}$ content of the melt inclusions most chemically similar to the matrix glass, which have $\mathrm{CO}_{2}=1079 \mathrm{ppm}$ : these inclusions likely 
trap the mixed magma prior to its extensive low pressure degassing, albeit they do not have the highest $\mathrm{CO}_{2} /$ ITE ratios we observe and therefore may have already lost some $\mathrm{CO}_{2}$. Most importantly, this choice is consistent with our use of the matrix glass trace element composition to calculate the enrichment factors. Our calculation is also independent of chosen $\mathrm{DM} \mathrm{CO}_{2}$ value, as it is determined by erupted $\mathrm{CO}_{2}$ content and $\bar{E}$ values.

Taking this value of $\mathrm{CO}_{2}$, Fig. 8k reports Miðfell source carbon content calculated using enrichment factors over a range of source Deep fractions (blue line). For $\mathrm{X}_{\text {Deep }}=0.47$, the bulk Miðfell source contains $690 \mathrm{ppm} \mathrm{CO}_{2}$ (Fig. \& green bar).

Mass balance between the DM and Deep components allows us to convert the bulk source $\mathrm{CO}_{2}$ (blue) into Deep $\mathrm{CO}_{2}$ (orange). Here our calculation does depend on knowing the $\mathrm{DM} \mathrm{CO}_{2}$ content, which has been previously constrained as $105 \pm 57$ ppm (black; Hauri et al. 2018). For $\mathrm{X}_{\text {Deep }}=0.47$, Deep has a $\mathrm{CO}_{2}$ content of $1350 \pm 350 \mathrm{ppm}$ (90\% confidence interval considering only propagated analytical and $\bar{E}$ uncertainties).

These calculations are robust for a number of different assumptions: (i) as Fig. 8f shows, the full range of source DM:Deep proportions predict a Deep $\mathrm{CO}_{2}$ content $>1000 \mathrm{ppm}$; (ii) if the modelling is repeated using more depleted melt inclusions, which are less likely to have undergone degassing and have peak $\mathrm{CO}_{2}$ of $300 \mathrm{ppm}$, then Deep compositions of $>1250 \mathrm{ppm} \mathrm{CO}_{2}$ are inferred; and (iii) adaptations to the model to explore the consequences of mixing fractional melts from two sources produce the same requirement of $>1000 \mathrm{ppm} \mathrm{CO}_{2}$ in the Deep source. 


\section{Summary \& Discussion}

We have shown that melt inclusions from the Icelandic Miðfell eruption record some of the highest $\mathrm{CO}_{2} / \mathrm{ITE}$ ratios reported in basalts, and that these inclusions reflect the composition of their mantle source. In comparison with Borgarhraun, Miðfell's noble gas and lithophile element composition argues for its source comprising a deep mantle component in addition to the depleted mantle common to Icelandic magmas. By combining existing work with our new carbon and trace element observations, we have been able to assign a carbon content to this deep component. We took the depleted mantle component to be that of the well-studied Borgarhraun eruption, which lacks primitive noble gas isotope signatures and has a source $\mathrm{CO}_{2}=105 \pm 57 \mathrm{ppm}$ (using $\mathrm{Ba}, \mathrm{Nb}$ estimates; Hauri et al. 2018). We estimate the deep mantle component to have a $\mathrm{CO}_{2}$ concentration of at least $1000 \mathrm{ppm}$ (preferred value $1350 \pm 350 \mathrm{ppm}$ ), which increases when the proportion of deep mantle component assumed to be present in the source is decreased.

\subsection{Recycled carbon?}

Xenon isotopes indicate that a significant proportion of Xe in Miðfell is derived from recycled air ( $\sim 90 \%$; Mukhopadhyay, 2012). If carbon was coupled to Xe during recycling, then some amount of carbon in the Miðfell source could also have come from recycling. However, it would be surprising if this component was the origin of the high $\mathrm{CO}_{2} /$ ITE ratios we observe. Miðfell lavas are not unique in containing recycled air: MORB have been interpreted to have a similar abundance of recycled air in their DMM source (Mukhopadhyay, 2012. Parai and Mukhopadhyay, 2015). Moreover, DMM, in contrast to the Icelandic mantle, is also known from $\mathrm{Pb}$ isotopes, $\mathrm{U}$ isotopes, and $\mathrm{CO}_{2} / \mathrm{Ba}$ ratios to have been pervasively contaminated by surface material (Andersen et al., 2015. Hirschmann, 2018). Despite this, MORB have lower $\mathrm{CO}_{2} /$ ITE and inferred 
source $\mathrm{CO}_{2}$ concentrations than Miðfell (e.g., Le Voyer et al., 2017). Therefore recycling, at least as seen by MORB, does not appear to significantly enrich carbon with respect to ITE's.

\subsection{Ancient mantle carbon?}

If Miðfell's carbon enrichment is a signature of entrained deep mantle material, to what extent is it ancient mantle carbon? This question is difficult to answer and will require more eruptions to be identified with primitive noble gas signatures and carbon undersaturated melt inclusions. However, the two eruptions we now have on Iceland with $\mathrm{CO}_{2}$ /ITE ratios that can be linked to their mantle sources, differ almost exclusively in their geochemistry by the presence of primitive noble gas signatures in Miðfell, which are absent in Borgarhraun - their lithophile radiogenic isotope compositions are otherwise very similar (Fig. 1p,c). This signature suggests an association between the primitive noble gases, which have been attributed to solar nebula ingassing during Earth's earliest history (Mukhopadhyay, 2012, Williams and Mukhopadhyay, 2018), and carbon. If true, it would imply a significant fraction of Earth's carbon came directly from the solar nebula rather than later accretion.

However, the coupling of high- ${ }^{3} \mathrm{He} /{ }^{4} \mathrm{He}$ with recycled material signatures (Brandon et al., 2007; Halldórsson et al. 2016b) could also suggest that deep mantle carbon is of a recycled origin, making it difficult to differentiate between primordial and recycled carbon from deep mantle material. Especially as there is no certainty that the nature of deep recycled material is the same as the upper mantle recycled material assumed to be present in the Borgarhraun source, which evidences no enrichment in carbon (Hauri et al. 2018).

\subsection{Size of the PM carbon reservoir}

If we assume that the Deep carbon estimate derived from Miðfell is representative of the global deep mantle reservoir, then we can calculate a revised 
601

602

mantle carbon budget. Estimates for the deep mantle fraction of the total mantle range from the seismically-defined $660 \mathrm{~km}$ transition zone, down to the seismically-defined D" layer above the core-mantle boundary. Figure 9 presents carbon content estimates of four potential deep mantle reservoir fractions: (i) 5\% representing the D" layer (blue; Tolstikhin and Hofmann, 2005); (ii) 20\% for the abyssal layer of the lower mantle, defined by $\mathrm{U} / \mathrm{K}$ mass balance (green; Arevalo et al. 2009); (iii) $42 \%$ for the mass of primitive mantle calculated by ${ }^{40} \mathrm{Ar}$ mass balance (orange; $90 \%$ confidence envelope in grey; this study and $\mathrm{Al}-$ lègre et al. 1996); and (iv) $75 \%$ for the lower mantle as defined by the $660 \mathrm{~km}$ seismic discontinuity (red; Hofmann, 1997).

The carbon content of the atmosphere, crust, and oceans combined (ACO) is $\sim 3.1 \times 10^{23} \mathrm{~g} \mathrm{CO}_{2}$ (Hirschmann, 2018). Carbon stored in the deep mantle, depending on mantle fraction, is therefore up to 14 times greater than the $\mathrm{ACO}$ carbon reservoir, while the DMM is approximately equal to the ACO (Fig. 9). Our calculations do not include the potential carbon contribution from the lithospheric mantle, which could be host to one AOC of carbon (Sleep 2009, Kelemen and Manning, 2015). These carbon reservoir estimates for the deep Earth are necessarily speculative, but comparable to the range of previous bulk mantle estimates (e.g., Halliday, 2013). Our carbon estimates are also a lower bound in two important respects: (i) if the deep mantle component in Miðfell is less than the high value we used, then the implied carbon content in it is higher; (ii) if the deep component contains recycled material that is enriched in $\mathrm{Ba}$ and $\mathrm{Nb}$, then our use of a BSE composition will have led to an underestimate of its carbon content. 
625

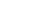

628

629

630

632 G.G. was funded by National Science Foundation (NSF) grant number NSF

6 Oз3 OCE-1459649. Ion microprobe analyses at the Northeast National Ion Micro-

634 probe Facility at Woods Hole Oceanographic Institution were partially subsi-

635 dized by the Instrumentation and Facilities Program, Division of Earth Sciences,

${ }_{636}$ NSF. Competing interests: The authors declare that they have no competing

637 financial interests. 


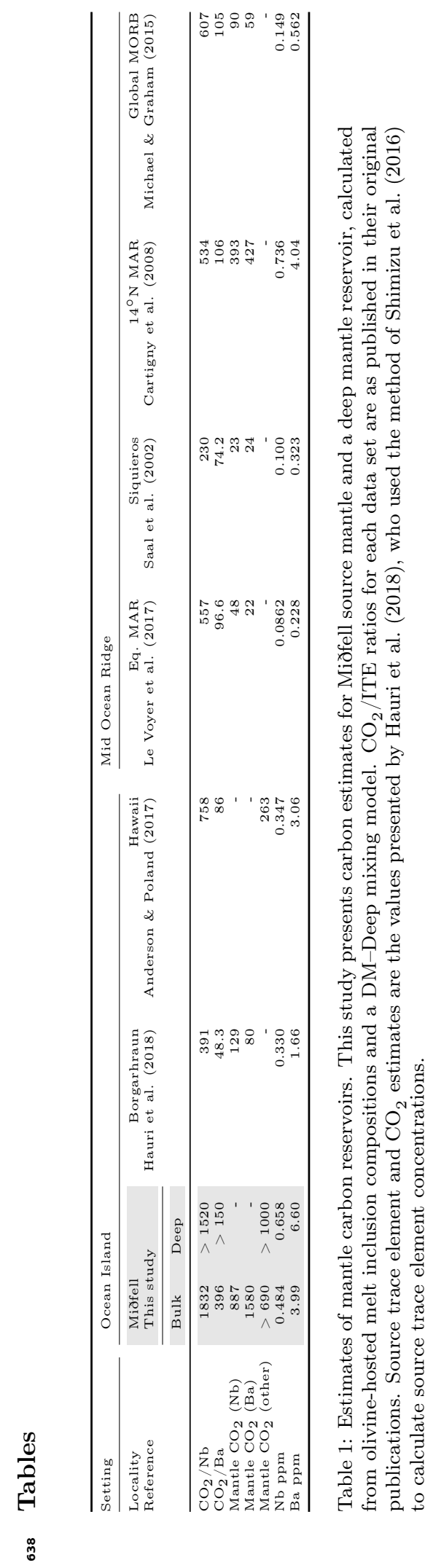




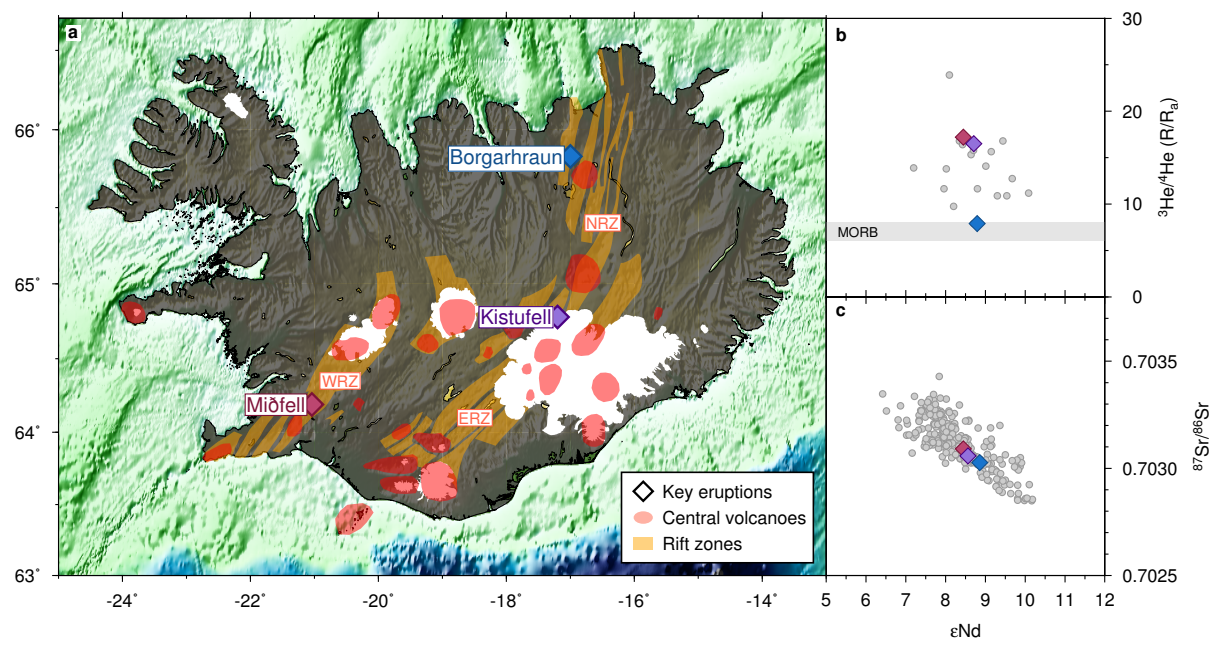

Figure 1: Icelandic eruptions discussed in this study: Miðfell (red), Kistufell (purple), and Borgarhraun (blue). Map of Iceland in (a) shows eruption locations, central volcanoes (red areas), and main rift zones (orange): WRZ, western rift zone; ERZ, eastern rift zone; and NRZ, northern rift zone. In (b) He isotope compositions relative to atmospheric ${ }^{3} \mathrm{He} /{ }^{4} \mathrm{He}$ $\left(\mathrm{R} / \mathrm{R}_{\mathrm{a}}\right)$ and in (c) Sr isotope compositions against $\epsilon \mathrm{Nd}$ for key eruptions (diamonds) and young Icelandic eruptions ( $<120 \mathrm{kyrs})$ from rift zones (grey). Kistufell and Miðfell show elevated ${ }^{3} \mathrm{He} /{ }^{4} \mathrm{He}$ with respect to Borgarhraun. Data compiled in Shorttle and Maclennan (2011). 

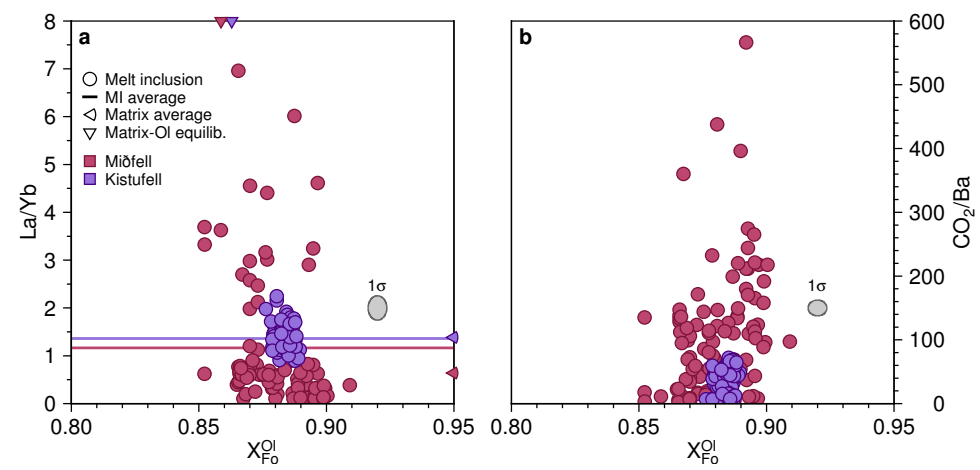

Figure 2: (a) La/Yb ratio of Miðfell (red) and Kistufell (purple) melt inclusions against host olivine forsterite content. Average melt inclusion La/Yb ratios are shown by horizontal lines, while matrix glass averages are indicated by arrowheads at $\mathrm{X}_{\mathrm{Fo}}^{\mathrm{Ol}}=0.95$. The olivine forsterite compositions in equilibrium with the matrix glasses are shown by inverted triangles at $\mathrm{La} / \mathrm{Yb}=8$. Melt inclusion variability is preserved with decreasing forsterite content in the Miðfell suite, while the Kistufell melt inclusions have much lower $\mathrm{La} / \mathrm{Yb}$ variability and are clustered within a smaller forsterite content range. (b) $\mathrm{CO}_{2} / \mathrm{Ba}$ against forsterite, indicating that the highest $\mathrm{CO}_{2} / \mathrm{Ba}$ ratios are preserved in the most forsteritic olivines. One sigma error ellipse plotted in grey. 

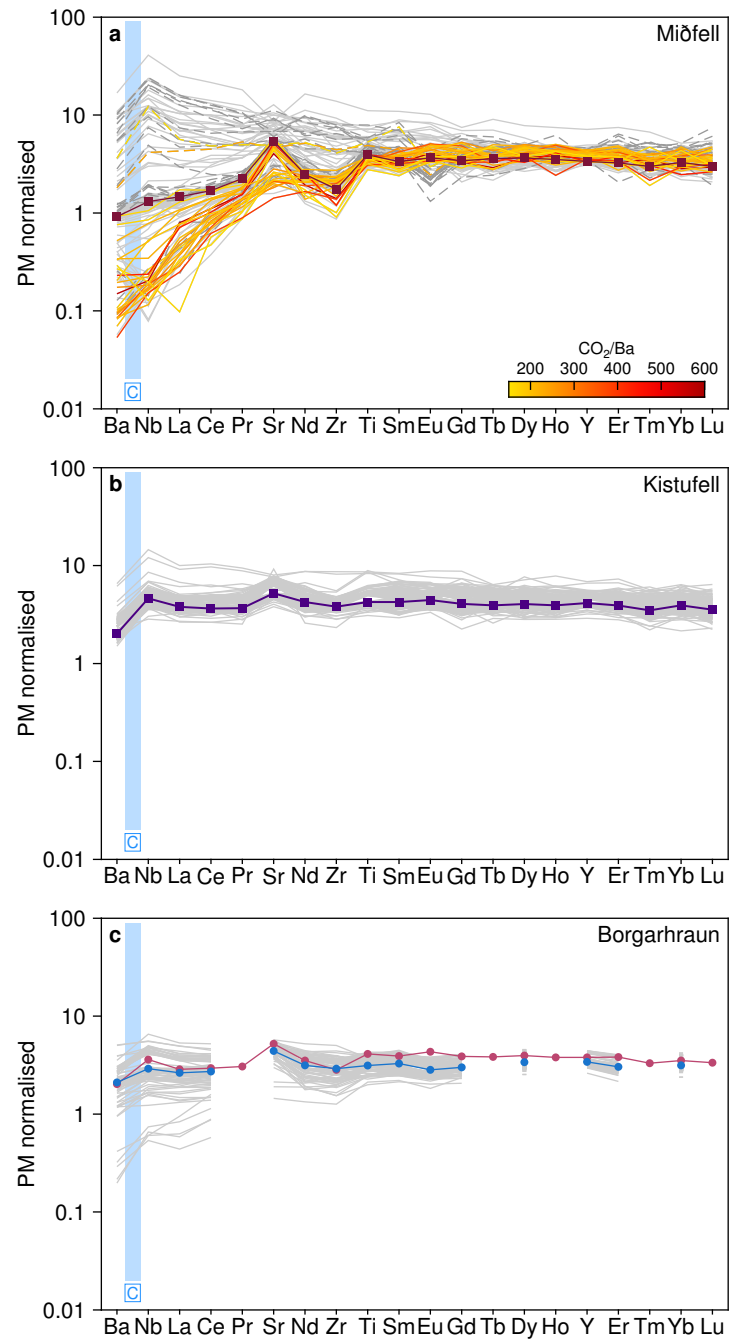

Figure 3: Trace element spider diagrams showing compositional variability in (a) Miðfell, (b) Kistufell, and (c) Borgarhraun (Hauri et al. 2018) melt inclusion suites, normalised to primitive mantle (PM; BSE composition, McDonough and Sun, 1995). Inclusions with $\mathrm{CO}_{2} / \mathrm{Ba}>150$ are coloured, the rest are grey (Borgarhraun melt inclusions have an average $\left.\mathrm{CO}_{2} / \mathrm{Ba} \sim 48\right)$. Matrix glass compositions are shown as dark squares. The likely position of carbon, given its measured compatibility (Rosenthal et al., 2015), is shown as a blue vertical line. In (c) the light red line and circles are the Miðfell average melt inclusion composition, and in light blue is the Borgarhraun melt inclusion average. Miðfell and Borgarhraun matrix glasses are very similar, but Miðfell shows greater trace element variability within the melt inclusion population. 

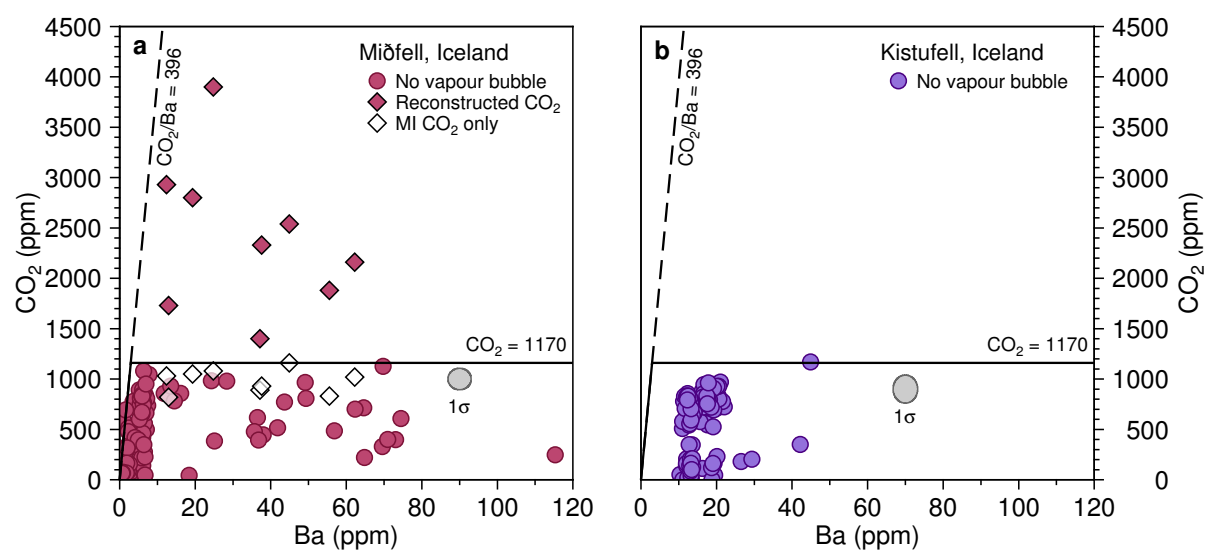

Figure 4: Variation in $\mathrm{CO}_{2}$ content as a function of Ba concentration for (a) Miðfell and (b) Kistufell melt inclusions (diamonds, with vapour bubbles; circles, without vapour bubbles). The maximum $\mathrm{CO}_{2}$ recovered from melt inclusion glass (circles and unfilled diamonds) is $1170 \mathrm{ppm}$, as shown by the horizontal line. Combined glass and vapour bubble $\mathrm{CO}_{2}$ measurements plot between this line and $\mathrm{CO}_{2} / \mathrm{Ba}=396$ (the maximum ratio preserved by a smooth trace element pattern melt inclusion), as shown by the dashed line. Miðfell contains melt inclusions with low enough Ba concentrations that they have likely avoided degassing, while Kistufell melt inclusions are too enriched and have all likely lost $\mathrm{CO}_{2}$. One sigma error ellipse plotted in grey. 

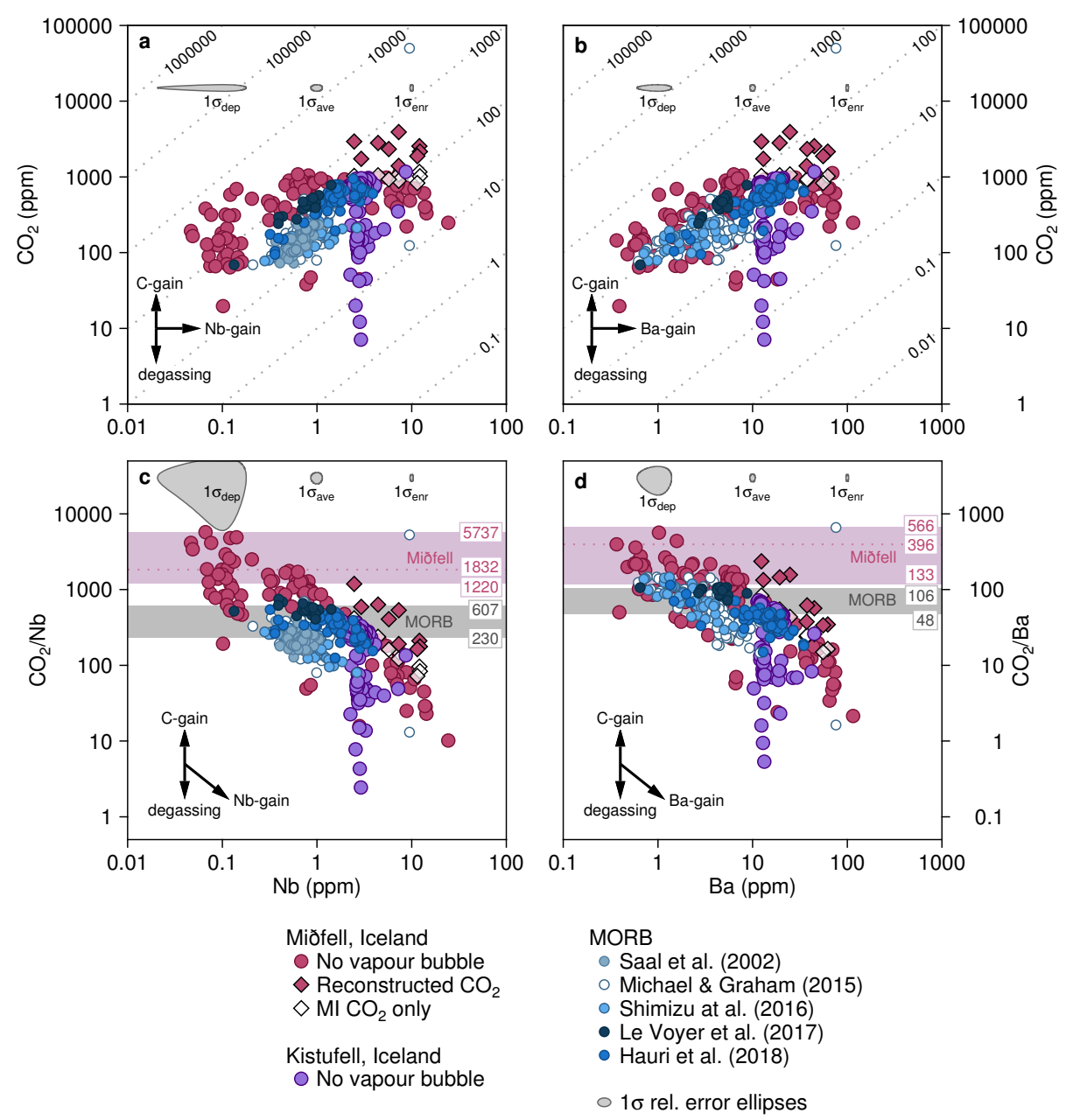

Figure 5: $\mathrm{CO}_{2}$ content against (a) $\mathrm{Nb}$ abundance and (b) $\mathrm{Ba}$ abundance, and $\mathrm{CO}_{2} / \mathrm{ITE}$ against ITE for (c) Nb and (d) Ba, for melt inclusion and glass suites. Miðfell melt inclusions (red) were measured at Edinburgh (circles) and Woods Hole Oceanic Institution (diamonds). Filled diamonds show reconstructed $\mathrm{CO}_{2}$ content, while empty diamonds are glass only $\mathrm{CO}_{2}$. Previously analysed suites are from Siquieros (light blue; Saal et al., 2002), Borgarhraun (royal blue; Hauri et al. 2018), and Equatorial Atlantic (dark blue; Le Voyer et al., 2017) melt inclusions, and MORB glasses (white, Michael and Graham 2015, sky blue, D-MORB, Shimizu et al. 2016). Dashed lines show constant $\mathrm{CO}_{2} / \mathrm{ITE}$ ratios in (a) \& (b). Light red regions in (c) \& (d) indicate the maximum $\mathrm{CO}_{2} /$ ITE ratios recorded (from high to low) in: (i) the whole population, (ii) melt inclusions with a smooth trace element pattern, and (iii) melt inclusions with matrix glass ITE concentration. Miðfell contains melt inclusions that are enriched in carbon with respect to MORB suites and Kistufell for a range of ITE concentrations. Grey bands show MORB source estimates. One sigma error ellipses are dependent on trace element concentration. 32 


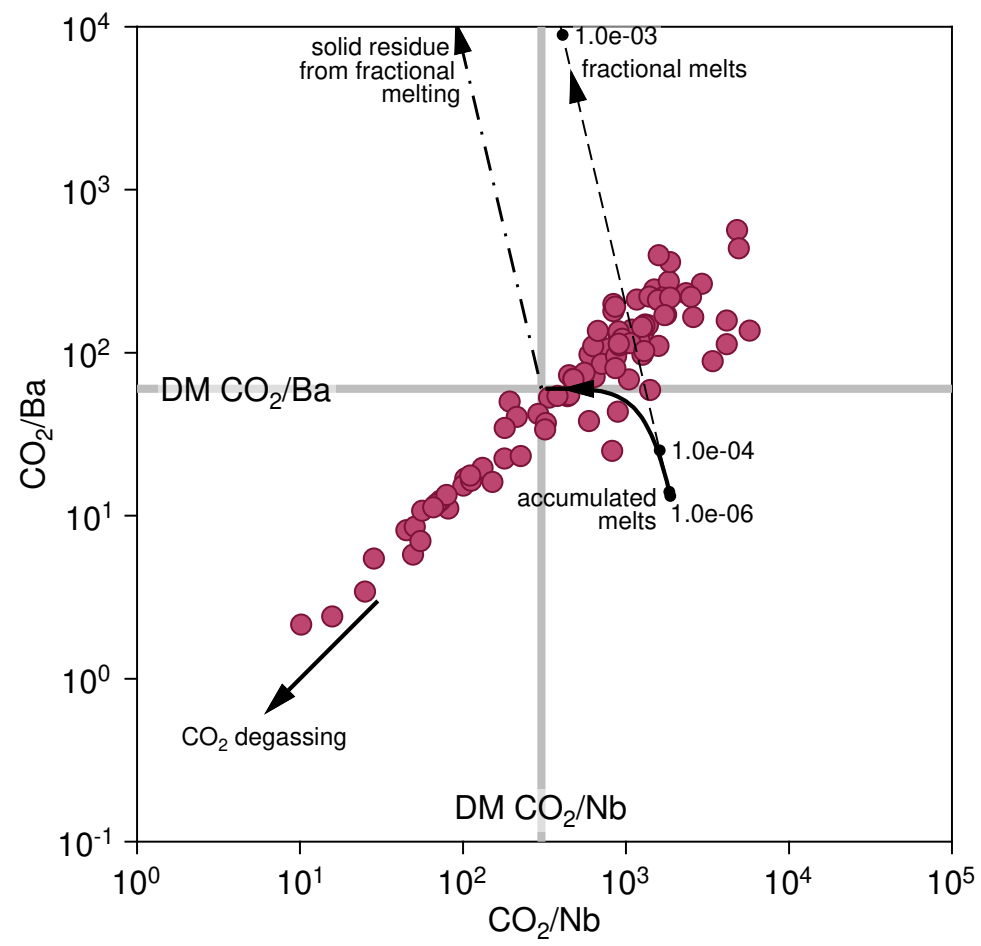

Figure 6: The relationship between $\mathrm{CO}_{2} / \mathrm{Nb}$ and $\mathrm{CO}_{2} / \mathrm{Ba}$ in Miðfell melt inclusions. The $\mathrm{CO}_{2}$ /ITE ratios of the depleted mantle component (DM), as inferred from the Borgarhraun eruption, are shown as grey bars. These ratios represent the starting source composition for modelling fractional melting. The composition of instantaneous melts of this source follow the dashed line, accumulated melts the solid line, and the residual solid the dashed-dotted line. Points along the instantaneous melts curve are labelled by melt fraction. The highest $\mathrm{CO}_{2}$ /ITE melts cannot be produced by fractional melting of a DM source. Partition coefficients for melting were taken from Rosenthal et al. (2015): $D_{\mathrm{C}}=0.00055, D_{\mathrm{Nb}}=0.0034$, and $D_{\mathrm{Ba}}=0.00012$. 


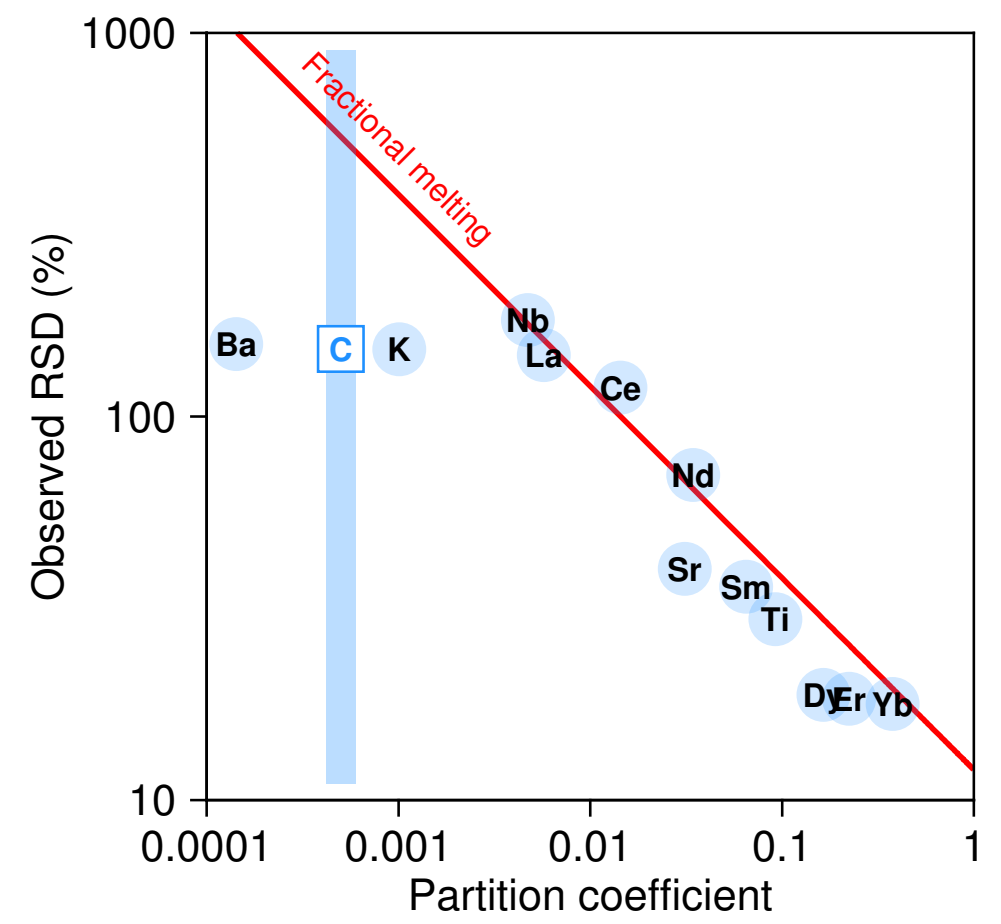

Figure 7: Trace element variability in Miðfell melt inclusions shown by observed relative standard deviation (RSD) of trace elements with varying incompatibility on mantle melting. The results of a pure fractional melting model and the partition coefficients for garnet peridotite melting are shown as a red solid line. The expected behaviour of carbon can be inferred from the blue vertical line, based on its measured compatibility (Rosenthal et al. 2015). Ba, K, $\mathrm{Nb}$, La show similar RSD, suggesting that they remained coupled during melting. 

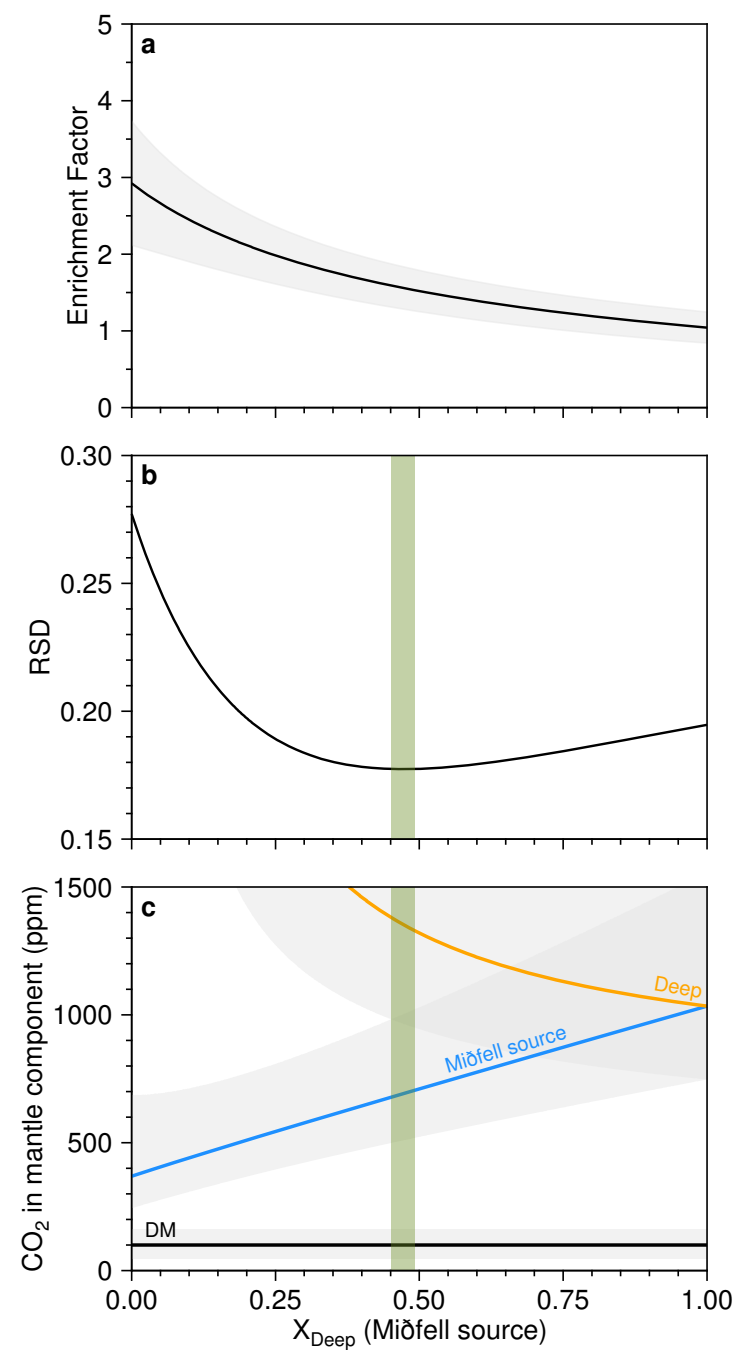

Figure 8: Estimating the fraction of deep mantle component ( $\left.\mathrm{X}_{\mathrm{Deep}}\right)$ in the Miðfell source (a $\& \mathrm{~b})$, and the $\mathrm{CO}_{2}$ concentration of the bulk Miðfell source and its depleted (DM) and deep (Deep) components (c). The best-fit mean enrichment factor $(\bar{E})$ calculated from $\mathrm{Ba}, \mathrm{K}, \mathrm{Nb}$ and La in Miðfell relative to a mixed source ( $\mathrm{a} ; 2 \sigma$ error as grey field) is defined by the $\mathrm{X}_{\text {Deep }}$ composition where relative standard deviation of the enrichment factor for the four elements is minimised (b; green band). In (c), the Miðfell source $\mathrm{CO}_{2}$ content was calculated using $\bar{E}$ and measured $\mathrm{CO}_{2}$ (=1079 ppm). The $\mathrm{CO}_{2}$ concentration of the Deep component (orange) was calculated by balancing the Miðfell source content with the DM component (105 \pm 57 ppm; black; $\mathrm{Ba}$ and $\mathrm{Nb}$ estimate average from Hauri et al. 2018). 90\% confidence envelopes in grey. 


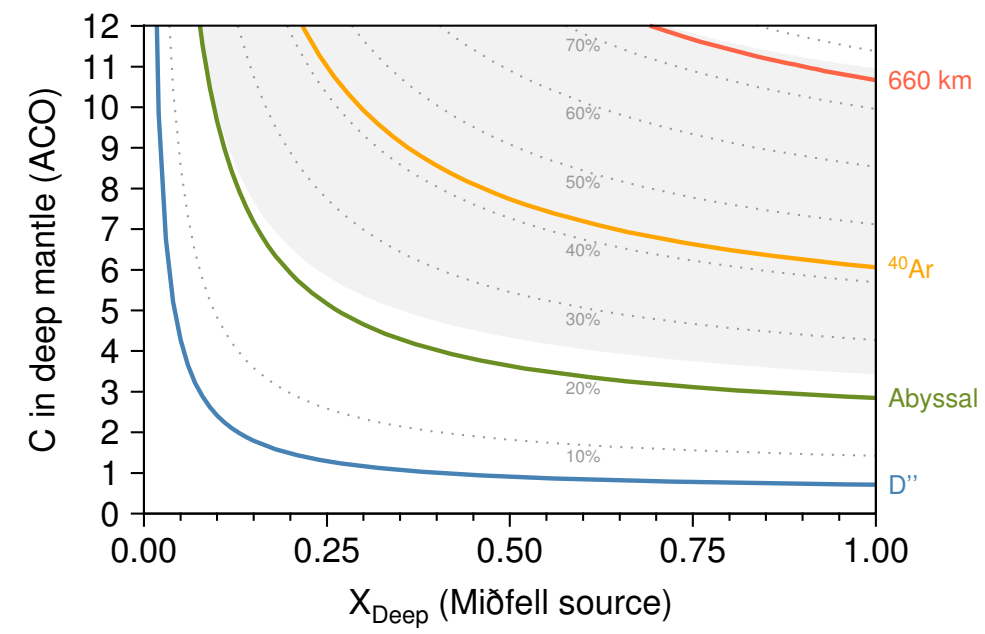

Figure 9: Estimates of deep mantle carbon reservoir mass $(\mathrm{ACO}=$ Atmosphere + Crust + Oceans $=3.1 \times 10^{23} \mathrm{~g} \mathrm{CO}_{2}$ ), using the Deep concentration curve in Fig. 8f for a range of mantle fractions (grey dotted lines). Four mantle fractions have been highlighted: (i) $5 \%$ representing the seismically-defined D" layer (blue; Tolstikhin and Hofmann 2005); (ii) 20\% for the abyssal layer of the lower mantle, defined by U/K mass balance (green; Arevalo et al. 2009); (iii) $42 \%$ for the mass of primitive mantle calculated by ${ }^{40} \mathrm{Ar}$ mass balance (orange; 90\% confidence envelope in grey; this study and Allègre et al. 1996); and (iv) $75 \%$ for the lower mantle as defined by the $660 \mathrm{~km}$ seismic discontinuity (red; Hofmann 1997). 


\section{References}

Allègre, C.J., Hofmann, A., O’Nions, K., 1996. The argon constraints on mantle structure. Geophysical Research Letters 23, 3555-3557.

Andersen, M.B., Elliott, T., Freymuth, H., Sims, K.W.W., Niu, Y., Kelley, K.A., 2015. The terrestrial uranium isotope cycle. Nature 517, 356-359.

Anderson, K.R., Poland, M.P., 2017. Abundant carbon in the mantle beneath Hawai'i. Nature Geoscience 10, 704-708.

Arevalo, R., McDonough, W.F., Luong, M., 2009. The K/U ratio of the silicate Earth: Insights into mantle composition, structure and thermal evolution. Earth and Planetary Science Letters 278, 361-369. doi 10.1016/j.epsl. 2008.12 .023

Brandon, A.D., Graham, D.W., Waight, T., Gautason, B., 2007. ${ }^{186}$ Os and ${ }^{187} \mathrm{Os}$ enrichments and high ${ }^{3} \mathrm{He} /{ }^{4} \mathrm{He}$ sources in the Earth's mantle: Evidence from Icelandic picrites. Geochimica et Cosmochimica Acta 71, 4570-4591.

Breddam, K., 2002. Kistufell: Primitive melt from the Iceland mantle plume. Journal of Petrology 43, 345-373.

Breddam, K., Kurz, M.D., Storey, M., 2000. Mapping out the conduit of the Iceland mantle plume with helium isotopes. Earth and Planetary Science Letters $176,45-55$.

Canil, D., 1990. Experimental study bearing on the absence of carbonate in mantle-derived xenoliths. Geology 18, 1011-1013.

Caracausi, A., Avice, G., Burnard, P.G., Füri, E., Marty, B., 2016. Chondritic xenon in the Earth's mantle. Nature 533, 82-85. doi $10.1038 /$ nature17434 
Cartigny, P., Pineau, F., Aubaud, C., Javoy, M., 2008. Towards a consistent mantle carbon flux estimate: Insights from volatile systematics $\left(\mathrm{H}_{2} \mathrm{O} / \mathrm{Ce}\right.$, $\left.\delta \mathrm{D}, \mathrm{CO}_{2} / \mathrm{Nb}\right)$ in the North Atlantic mantle $\left(14^{\circ} \mathrm{N}\right.$ and $\left.34^{\circ} \mathrm{N}\right)$. Earth and Planetary Science Letters 265, 672-685.

Danyushevsky, L.V., Della-Pasqua, F.N., Sokolov, S., 2000. Re-equilibration of melt inclusions trapped by magnesian olivine phenocrysts from subductionrelated magmas: petrological implications. Contributions to Mineralogy and Petrology 138, 68-83. doi:10.1007/PL00007664.

Dasgupta, R., Hirschmann, M.M., 2010. The deep carbon cycle and melting in Earth's interior. Earth and Planetary Science Letters 298, 1-13.

Füri, E., Hilton, D.R., Halldórsson, S.A., Barry, P.H., Hahm, D., Fischer, T.P., Grönvold, K., 2010. Apparent decoupling of the He and Ne isotope systematics of the Icelandic mantle: The role of He depletion, melt mixing, degassing fractionation and air interaction. Geochimica et Cosmochimica Acta 74, 33073332.

Gonnermann, H.M., Mukhopadhyay, S., 2007. Non-equilibrium degassing and a primordial source for helium in ocean-island volcanism. Nature 449, 10371040. doi:10.1038/nature06240

Gurenko, A.A., Chaussidon, M., 1995. Enriched and primitive melts included in olivine from Icelandic tholeiites: origin by continuous melting of a single mantle column. Geochimica et Cosmochimica Acta 59, 2905-2917.

Gurenko, A.A., Sobolev, A.V., 2006. Crust-primitive magma interaction beneath neovolcanic rift zone of Iceland recorded in gabbro xenoliths from Midfell, SW Iceland. Contributions to Mineralogy and Petrology 151, 495-520. 
Halldórsson, S.A., Barnes, J.D., Stefánsson, A., Hilton, D.R., Hauri, E.H., Marshall, E.W., 2016a. Subducted lithosphere controls halogen enrichments in the Iceland mantle plume source. Geology 44, 679-682.

Halldórsson, S.A., Hilton, D.R., Barry, P.H., Füri, E., Grönvold, K., 2016b. Recycling of crustal material by the Iceland mantle plume: New evidence from nitrogen elemental and isotope systematics of subglacial basalts. Geochimica et Cosmochimica Acta 176, 206-226. doi $10.1016 / \mathrm{j} \cdot \mathrm{gca} .2015 .12 .021$

Halliday, A.N., 2013. The origins of volatiles in the terrestrial planets. Geochimica et Cosmochimica Acta 105, 146-171.

Harrison, D., Burnard, P., Turner, G., 1999. Noble gas behaviour and composition in the mantle: constraints from the Iceland Plume. Earth and Planetary Science Letters 171, 199-207.

Hartley, M.E., Neave, D.A., Maclennan, J., Edmonds, M., Thordarson, T., 2015. Diffusive over-hydration of olivine-hosted melt inclusions. Earth and Planetary Science Letters 425, 168-178.

Hauri, E.H., Maclennan, J., McKenzie, D., Gronvold, K., Oskarsson, N., Shimizu, N., 2018. $\mathrm{CO}_{2}$ content beneath northern Iceland and the variability of mantle carbon. Geology 46, 55-58.

Hayes, J.M., Waldbauer, J.R., 2006. The carbon cycle and associated redox processes through time. Philosophical Transactions of the Royal Society B $361,931-950$.

Hirschmann, M.M., 2016. Constraints on the early delivery and fractionation of Earth's major volatiles from $\mathrm{C} / \mathrm{H}, \mathrm{C} / \mathrm{N}$, and $\mathrm{C} / \mathrm{S}$ ratios. American Mineralogist 101, 540-553. 
711 Hirschmann, M.M., 2018. Comparative deep Earth volatile cycles: The case

for $\mathrm{C}$ recycling from exosphere/mantle fractionation of major $\left(\mathrm{H}_{2} \mathrm{O}, \mathrm{C}, \mathrm{N}\right)$ volatiles and from $\mathrm{H}_{2} \mathrm{O} / \mathrm{Ce}, \mathrm{CO}_{2} / \mathrm{Ba}$, and $\mathrm{CO}_{2} / \mathrm{Nb}$ exosphere ratios. Earth and Planetary Science Letters 502, 262-273. doi:10.1016/j.epsl.2018.08. 023

Hofmann, A.W., 1997. Mantle geochemistry: the message from oceanic volcanism. Nature 385, 219-229.

Jenkins, J., Cottaar, S., White, R.S., Deuss, A., 2016. Depressed mantle discontinuities beneath Iceland: Evidence of a garnet controlled $660 \mathrm{~km}$ discontinuity? Earth and Planetary Science Letters 433, 159-168.

Kelemen, P.B., Manning, C.E., 2015. Reevaluating carbon fluxes in subduction zones, what goes down, mostly comes up. Proceedings of the National Academy of Sciences 112, E3997-E4006. doi 10.1073/pnas.1507889112.

Kokfelt, T., Hoernle, K., Hauff, F., Fiebig, J., Werner, R., Garbe-Schönberg, D., 2006. Combined trace element and $\mathrm{Pb}-\mathrm{Nd}-\mathrm{Sr}-\mathrm{O}$ isotope evidence for recycled oceanic crust (upper and lower) in the Iceland mantle plume. Journal of Petrology 47, 1705-1749.

Le Voyer, M., Kelley, K., Cottrell, E., Hauri, E., 2017. Heterogeneity in mantle carbon content from $\mathrm{CO}_{2}$-undersaturated basalts. Nature Communications 8,14062 .

Maclennan, J., 2008a. Concurrent mixing and cooling of melts under Iceland. Journal of Petrology 49, 1931-1953. doi 10.1093/petrology/egn052.

Maclennan, J., 2008b. Lead isotope variability in olivine-hosted melt inclusions from Iceland. Geochimica et Cosmochimica Acta 72, 4159-4176. 
Maclennan, J., 2017. Bubble formation and decrepitation control the $\mathrm{CO}_{2}$ content of olivine-hosted melt inclusions. Geochemistry, Geophysics, Geosystems 18, 597-616. doi $10.1002 / 2016 \mathrm{GC} 006633$

Maclennan, J., McKenzie, D., Grönvold, K., 2001. Plume-driven upwelling under central Iceland. Earth and Planetary Science Letters 194, 67-82.

Maclennan, J., McKenzie, D., Hilton, F., Gronvöld, K., Shimizu, N., 2003. Geochemical variability in a single flow from northern Iceland. Journal of Geophysical Research 108. doi:10.1029/2000JB000142.

Marty, B., 2012. The origins and concentrations of water, carbon, nitrogen and noble gases on Earth. Earth and Planetary Science Letters 313-314, 56-66.

Matthews, S., Shorttle, O., Rudge, J.F., Maclennan, J., 2017. Constraining mantle carbon: $\mathrm{CO}_{2}$-trace element systematics in basalts and the roles of magma mixing and degassing. Earth and Planetary Science Letters 480, 114. doi $10.1016 / \mathrm{j} \cdot \mathrm{epsl} \cdot 2017.09 .047$

Matzen, A.K., Baker, M.B., Beckett, J.R., Stolper, E.M., 2011. Fe-Mg partitioning between olivine and high-magnesian melts and the nature of Hawaiian parental liquids. Journal of Petrology 52, 1243-1263. doi 10.1093/ petrology/egq089.

McDonough, W.F., Sun, S., 1995. The composition of the Earth. Chemical Geology 120, 223-253.

Michael, P.J., Graham, D.W., 2015. The behavior and concentration of $\mathrm{CO}_{2}$ in the suboceanic mantle: Inferences from undegassed ocean ridge and ocean island basalts. Lithos 236-237, 338-351.

Mojzsis, S.J., Harrison, T.M., Pidgeon, R.T., 2001. Oxygen-isotope evidence 
from ancient zircons for liquid water at the Earth's surface 4,300 Myr ago. Nature 409, 178-181.

Montelli, R., Nolet, G., Dahlen, F.A., Masters, G., 2006. A catalogue of deep mantle plumes: New results from finite-frequency tomography. Geochemistry, Geophysics, Geosystems 7. doi:10.1029/2006GC001248

Mukhopadhyay, S., 2012. Early differentiation and volatile accretion recorded in deep-mantle neon and xenon. Nature 486, 101-104.

Nestola, F., Korolev, N., Koylova, M., Rotiroti, N., Pearson, D.G., Pamato, M.G., Alvaro, M., Peruzzo, L., Gurney, J.J., Moore, A.E., Davidson, J., 2018. $\mathrm{CaSiO}_{3}$ perovskite in diamond indicates the recycling of oceanic crust into the lower mantle. Nature 555, 237-241. doi $10.1038 /$ nature25972

Palme, H., O’Neill, H., 2014. Cosmochemical Estimates of Mantle Composition, in: Treatise on Geochemistry. 2 ed.. Elsevier. volume 3, pp. 1-39. doi 10. 1016/B978-0-08-095975-7.00201-1.

Parai, R., Mukhopadhyay, S., 2015. The evolution of MORB and plume mantle volatile budgets: Constraints from fission Xe isotopes in Southwest Indian Ridge basalts. Geochemistry, Geophysics, Geosystems 16, 719-735. doi:10. $1002 / 2014 \mathrm{GC} 005566$.

Peate, D.W., Breddam, K., Baker, J.A., Kurz, M.D., Barker, A.K., Prestvik, T., Grassineau, N., Skovgaard, A.C., 2010. Compositional characteristics and spatial distribution of enriched Icelandic mantle components. Journal of Petrology 51, 1447-1475. doi:10.1093/petrology/egq025.

Peters, B.J., Carlson, R.W., Day, J.M.D., Horan, M.F., 2018. Hadean silicate differentiation preserved by anomalous ${ }^{142} \mathrm{Nd} /{ }^{144} \mathrm{Nd}$ ratios in the Réunion hotspot source. Nature 555. doi:10.1038/nature25754 
Rosenthal, A., Hauri, E., Hirschmann, M., 2015. Experimental determination of $\mathrm{C}, \mathrm{F}$, and $\mathrm{H}$ partitioning between mantle minerals and carbonated basalt, $\mathrm{CO}_{2} / \mathrm{Ba}$ and $\mathrm{CO}_{2} / \mathrm{Nb}$ systematics of partial melting, and the $\mathrm{CO}_{2}$ contents of basaltic source regions. Earth and Planetary Science Letters 412, 77-87.

Saal, A.E., Hauri, E., Langmuir, C.H., Perfit, M., 2002. Vapour undersaturation in primitive mid-ocean-ridge basalt and the volatile content of Earth's upper mantle. Nature 419, 451-455.

Schiano, P., Allègre, C.J., Dupré, B., Lewin, E., Joron, J.L., 1993. Variability of trace elements in basaltic suites. Earth and Planetary Science Letters 119, $37-51$.

Shimizu, K., Saal, A.E., Myers, C.E., Nagle, A.N., Hauri, E.H., Forsyth, D.W., Kamenetsky, V.S., Niu, Y., 2016. Two-component mantle melting-mixing model for the generation of mid-ocean ridge basalts: Implications for the volatile content of the Pacific upper mantle. Geochimica et Cosmochimica Acta 176, 44-80.

Shishkina, T., Botcharnikov, R., Holtz, F., Almeev, R., Portnyagin, M., 2010. Solubility of $\mathrm{H}_{2} \mathrm{O}$ - and $\mathrm{CO}_{2}$-bearing fluids in tholeiitic basalts at pressures up to 500 MPa. Chemical Geology 277, 115-125.

Shorttle, O., 2015. Geochemical variability in MORB controlled by concurrent mixing and crystallisation. Earth and Planetary Science Letters 424, 1-14.

Shorttle, O., Maclennan, J., 2011. Compositional trends of Icelandic basalts: Implications for short-lengthscale lithological heterogeneity in mantle plumes. Geochemistry, Geophysics, Geosystems 12. doi:10.1029/2011GC003748.

Shorttle, O., Maclennan, J., Piotrowski, A.M., 2013. Geochemical provincialism in the Iceland plume. Geochimica et Cosmochimica Acta 122, 363-397. 
Sleep, N.H., 2009. Stagnant lid convection and carbonate metasomatism of the deep continental lithosphere. Geochemistry, Geophysics, Geosystems 10. doi $10.1029 / 2009 \mathrm{GC} 002702$.

Sobolev, A.V., Hofmann, A.W., Brügmann, G., Batanova, V.G., Kuzmin, D.V., 2008. A quantitative link between recycling and osmium isotopes. Science 321,321

Sobolev, A.V., Hofmann, A.W., Sobolev, S.V., Nikogosian, I.K., 2005. An olivine-free mantle source of Hawaiian shield basalts. Nature 434, 412-417.

Stracke, A., 2012. Earth's heterogeneous mantle: a product of convection driven interaction between crust and mantle. Chemical Geology 330-331, 274-299.

Stracke, A., Zindler, A., Salters, V.J.M., McKenzie, D., Blichert-Toft, J., Albarède, F., Grönvold, K., 2003. Theistareykir revisited. Geochemistry, Geophysics, Geosystems 4. doi 10.1029/2001GC000201

Thirlwall, M.F., Gee, M.A.M., Taylor, R.N., Murton, B.J., 2004. Mantle components in Iceland and adjacent ridges investigated using double-spike $\mathrm{Pb}$ isotope ratios. Geochimica et Cosmochimica Acta 68, 361-386.

Tolstikhin, I., Hofmann, A.W., 2005. Early crust on top of the Earth's core. Physics of the Earth and Planetary Interiors 148, 109-130. doi $10.1016 / j$. pepi.2004.05.011.

Trieloff, M., Kunz, J., 2005. Isotope systematics of noble gases in the Earth's mantle: possible sources of primordial isotopes and implications for mantle structure. Physics of the Earth and Planetary Interiors 148, 13-38.

Trieloff, M., Kunz, J., Clague, D.A., Harrison, D., Allègre, C.J., 2000. The nature of pristine noble gases in mantle plumes. Science 288, 1036-1038. 
${ }_{833}$ Walker, J.C.G., Hayes, P.B., Kasting, J.F., 1981. A negative feedback mecha${ }_{\mathbf{8 3 4}}$ nism for the long-term stabilization of Earth's surface temperature. Journal 835 of Geophysical Research 86, 9776-9782.

${ }_{836}$ Williams, C.D., Mukhopadhyay, S., 2018. Capture of nebular gases during ${ }_{837}^{837}$ Earth's accretion is preserved in deep-mantle neon. Nature doi 10.1038/ 838 S41586-018-0771-1.

8з9 Workman, R.K., Hart, S.R., 2005. Major and trace element composition of the 840 depleted MORB mantle (DMM). Earth and Planetary Science Letters 231, ${ }_{841} \quad 53-72$. doi $10.1016 / \mathrm{j} \cdot$ epsl.2004.12.005.

${ }_{842}$ Yuan, K., Romanowicz, B., 2017. Seismic evidence for partial melting at the 843 root of major hot spot plumes. Science 357, 393-397. 